\title{
EVALUATION OF HEPATITIS A SEROLOGY IN A TERTIARY CARE HOSPITAL IN ANKARA
}

\author{
Ankara'da Üçüncü Basamak Bir Hastanede Hepatit A Serolojisinin Değerlendirilmesi
}

\author{
Sabahat ÇEKEN ${ }^{1}$ (I), Çiğdem SÖNMEZ² \\ ${ }^{I}$ Dr. Abdurrahman Yurtaslan Onkoloji EAH, Enfeksiyon Hast. ve Klinik Mikrobiyoloji Kliniği, ANKARA, TÜRKIYE \\ ${ }^{2}$ Dr. Abdurrahman Yurtaslan Onkoloji EAH, Biyokimya Bölümü, ANKARA, TÜRKIYE
}

Objective: Hepatitis A virus (HAV) is a common cause of acute hepatitis in developing countries. The aim of this study is to investigate the serology of HAV infection in a tertiary care hospital in Ankara, and to review the change of the epidemiology of HAV infection.

Material and Methods: Patients who were tested for anti HAV IgG for any reason other than acute hepatitis during the two years period, between October 1, 2018 and October 1, 2020, and older than 18 years were retrospectively analysed, according to age groups. People younger than 18 and who had immunisation history were excluded. The age and sex of the patients and anti HAV IgG levels were recorded.

Results: The mean age of 3338 participants was $41 \pm 17.3$ years. One thousand eight hundred eighty-two (56.4\%) of the participants were female. Anti HAV IgG was positive in $2551(76.5 \%)$ of them. The lowest positivity was found in the $18-20$ age group as $31 \%$. The rate of HAV IgG seropositivity increased by age and it was statistically significant $(\mathrm{p}=0.0001)$.

Conclusion: Although hepatitis A vaccine is included in routine vaccination, there is a younger population sensitive to hepatitis A, especially below the age of 30 , in our country. We think it would be beneficial to vaccinate adolescents and young adults.

Keywords: Hepatitis A, HAV IgG, serology
Amaç: Hepatit A virüsü (HAV) gelişmekte olan ülkelerde yaygın görülen, akut hepatit etkeni bir virüstür. Bu çalışmanın amacı Ankara'da üçüncü basamak bir hastanede hepatit A serolojisini ve değişen epidemiyolojisini incelemektir.

Gereç ve Yöntemler: 1 Ekim 2018 - 1 Ekim 2020 tarihleri arasında, akut hepatit dışında herhangi bir nedenle anti-HAV IgG testi bakılan hastalardan, 18 yaş ve üstündekiler, yaş gruplarına gore retrospektif olarak incelendi. Hepatit A aşısı olanlar çalışmaya dahil edilmedi. Katılımcıların yaş ve cinsiyetleri ve Anti HAV IgG değerleri kaydedildi.

Bulgular: Çalışmaya alınan 3338 kişinin yaş ortalamas1 41 \pm 17.3 idi. Katılımciların 1882'si (\%56.4) kadın idi. Katılımcıların 2551'inin (\%76.5) Anti HAV IgG testi pozitif idi. En düşük pozitiflik \%31 olarak, 18-20 yaş grubunda bulundu. Yaş ilerledikçe HAV IgG pozitiflik oranının arttı̆̆ görüldü. $\mathrm{Bu}$ istatistiksel olarak da anlamlıydı $(\mathrm{P}=0,0001)$.

Sonuç: Hepatit A aşısı rutin aşılamaya girmesine rağmen, ülkemizde, özellikle 30 yaş altında, hepatit A'ya duyarlı bir kesim bulunmaktadır. Adolesan ve genç yetişkinlerin aşılanmasının faydalı olacağını düşünmekteyiz.

Anahtar Kelimeler: Hepatit A, HAV IgG, seroloji 


\section{INTRODUCTION}

Hepatitis A virus (HAV) is a common cause of acute hepatitis, especially in developing countries. The illness is transmitted by fecal oral route (1). Every year, 1.4 million hepatitis A infections are seen in the world. Although the disease is self-limiting, in a small group of cases $(0.14-0.35 \%)$ it can cause fulminant hepatitis and death, especially when seen at an advanced age (2). Symptomatic hepatitis A with or without jaundice has been reported as $50-75 \%$ in adults. This rate is $10 \%$ in children younger than 5 years old (3). In addition, prolonged hepatitis causes a long stay in the hospital and loss of workforce. The world is divided into high, medium and low endemicity regions in terms of the incidence of hepatitis A infection. While India, Far East, South Africa, South America and Asia are high endemicity regions, our country is among the middle endemicity countries $(4,5)$.

However, with the improvement of living conditions and socioeconomic status and better water and food sanitation, the number of hepatitis A infection has decreased while the proportion of people vulnerable to HAV has increased. For this reason, in our country hepatitis A vaccine was included in the child vaccination program in 2012. However, there is still a group in the community that can be affected by Hepatitis A in case of an outbreak. Therefore, the prevalence of hepatitis A should be evaluated according to age groups to determine this group. In this study, it was aimed to examine the seroprevalence of HAV according to age groups in the patients who admitted to our hospital.

\section{MATERIALS AND METHODS}

A retrospective cohort study was conducted in Infectious Diseases clinic of a teaching hospital with 500 beds in Ankara. Ethics committee approval was obtained (Dr. Abdurrahman Yurtaslan Oncology Hospital Ethics Committe of Clinical Research; date:
13.01.2021, issue number: 2021-01/935). The study was conducted in a period of two years between October 1, 2018 - October 1, 2020. Patients aged $\geq 18$ years who were tested for anti HAV IgG were included. The people younger than 18 years, who had vaccination history or who had acute hepatitis or elevation of liver function tests were excluded.

\section{Statistical Analysis}

The data of the patients, like age, sex and anti HAV IgG results were taken from our hospital's computerized medical record system. If the patient was tested more than once, the first test was included. Anti HAV antibodies in serum samples were analyzed with chemiluminescence microparticle immunoassay by Architect 2000 (Abbott Laboratories, Illinois, USA). Samples with anti HAV IgG titer $\geq 1 \mathrm{~S} / \mathrm{CO}$ were evaluated as positive and titers $<1 \mathrm{~S} / \mathrm{CO}$ as negative.

\section{RESULTS}

The study population included 3338 participants. The median age was $41 \pm 17.3$ (range:18-97). Anti HAV IgG was positive in 2551 (76.5\%) and negative in 787 $(23.5 \%)$ of participants. The lowest seropositivity was found in the 18-20 age group (31\%) and the highest was in people older than 55. It was observed that the rate of HAV IgG positivity increased in parallel with the age group and it was statistically significant. ( $p=0,0001$, Spearman correlation analysis $r=-0,558)$. Anti HAV IgG results according to age groups are given in Table- 1 . One thousand eight hundred eighty-two $(56.4 \%)$ of the participants were female and $1456(43.6 \%)$ of them were male. One thousand for hundred and seven $(74.8 \%)$ of the female participants and $1144(78.6 \%)$ of the males were HAV IgG positive. There was no statistically significant difference between male and female participants in terms of HAV seropositivity. ( $p>0.05)$. HAV IgG seropositivity according to age and sex is given in Table 2. 
Table 1. Anti HAV IgG results according to age groups

\begin{tabular}{lcccc}
\hline Age group & HAV Ig G Positive, $\mathbf{n}(\boldsymbol{\%})$ & HAV Ig G Negative & Total, & $\boldsymbol{p}$ \\
$\mathbf{1 8 - 2 0}$ & $93(31)$ & $207(69)$ & 300 & 0.0001 \\
$\mathbf{2 1 - 2 5}$ & $171(40.6)$ & $250(59.4)$ & 421 & \\
$\mathbf{2 6 - 3 0}$ & $186(54.5)$ & $155(45.4)$ & 341 \\
$\mathbf{3 1 - 3 5}$ & $218(739)$ & $77(26.1)$ & 295 \\
$\mathbf{3 6 - 4 0}$ & $337(86.2)$ & $54(13.8)$ & 391 \\
$\mathbf{4 1 - 4 5}$ & $333(94)$ & $21(6)$ & 354 \\
$\mathbf{4 6 - 5 0}$ & $316(96)$ & $13(4)$ & 329 \\
$\mathbf{5 1 - 5 5}$ & $274(97.8)$ & $6(2.2)$ & 280 \\
$>\mathbf{5 5}$ & $623(99.4)$ & $4(0.06)$ & 627 \\
Total & $2551(76.5)$ & $787(23.5)$ & 3338 \\
\hline
\end{tabular}

Table 2: Anti HAV IgG results according to age and sex

\begin{tabular}{lcccccc}
\hline & \multicolumn{3}{c}{ Female } & & & Male \\
\cline { 2 - 6 } Age group & HAV Ig G & HAV Ig G & Total & HAV Ig G & HAV Ig G & Total \\
& Positive & Negative & & Positive & Negative & \\
& $\mathrm{n}(\%)$ & $\mathrm{n}(\%)$ & $\mathrm{n}$ & $\mathrm{n}(\%)$ & $\mathrm{n}(\%)$ & $\mathrm{n}$ \\
\hline $\mathbf{1 8 - 2 0}$ & $62(33)$ & $126(67)$ & 188 & $31(27.7)$ & $81(72.3)$ & 112 \\
$\mathbf{2 1 - 2 5}$ & $117(42)$ & $161(58)$ & 278 & $54(37.8)$ & $89(62.2)$ & 143 \\
$\mathbf{2 6 - 3 0}$ & $105(53.8)$ & $90(46.2)$ & 195 & $81(55.5)$ & $65(44.5)$ & 146 \\
$\mathbf{3 1 - 3 5}$ & $110(72.8)$ & $41(27.2)$ & 151 & $108(75)$ & $36(25)$ & 144 \\
$\mathbf{3 6 - 4 0}$ & $197(86.4)$ & $31(13.6)$ & 228 & $140(86)$ & $23(14)$ & 163 \\
$\mathbf{4 1 - 4 5}$ & $187(93.5)$ & $13(6.5)$ & 200 & $146(94.8)$ & $8(5.2)$ & 154 \\
$\mathbf{4 6 - 5 0}$ & $177(96.2)$ & $7(3.8)$ & 184 & $139(95.9)$ & $6(4.1)$ & 145 \\
$\mathbf{5 1 - 5 5}$ & $134(98.5)$ & $2(1.5)$ & 136 & $140(97.2)$ & $4(2.8)$ & 144 \\
$>\mathbf{5 5}$ & $318(98.8)$ & $4(1.2)$ & 322 & $305(100)$ & $0(0)$ & 305 \\
Total & $1407(74.8)$ & $475(25.2)$ & 1882 & $1144(78.6)$ & $312(21.4)$ & 1456 \\
\hline
\end{tabular}

\section{DISCUSSION}

HAV is a member of the genus Hepatovirus in the Picornaviridae family. It is a non-enveloped, single stranded RNA virus with icosahedral symmetry and is $27 \mathrm{~nm}$ in size (6). It was defined by Feinstone et al in
1973 (7). HAV is transmitted from person to person via the fecal oral route. Contaminated water or food that are not washed well and eaten raw play an important role in contamination. It can be transmitted one week before and 2 weeks after the acute hepatitis infection, and the virus can also be transmitted from asymptomatic cases. 
HAV can be transmitted by using intravenous drugs, shared needles, with blood transfusion and sexual intercourse as well (3).

HAV is the most common cause of acute viral hepatitis. Acute HAV infection may appear asymptomatic, subclinical or symptomatic, with or without jaundice. While the disease is usually asymptomatic or subclinical under the age of 15, the frequency of symptomatic infection increases with age. In the case of cholestatic hepatitis or the hepatitis form that goes with exacerbations, the disease may last for months and this may cause loss of workforce. The disease rarely can also be fulminant and mortal (8).

HAV infection is more common and has high seroprevalence especially in areas with low socioeconomic level, in developing countries, in regions with poor infrastructure and hygiene conditions. Our country is in the middle endemicity region in terms of HAV infection (9). World Health Organization (WHO) does not recommend routine vaccination in regions where HAV infection is highly endemic, as the disease is seen in early childhood. Since outbreaks may occur from time to time, vaccination is recommended in moderately endemic regions like our country (10). Due to the routine vaccination program that was implemented in our country in 2012, children born in 2012 and after are immune to hepatitis A (11). However, there is HAV susceptible population in adolescents and young adults.

Studies have shown that seroprevalence of HAV can vary in different regions of our country. In the study of Ceyhan et al in 2005-2006, while the western and central Anatolian regions of Turkey were in the middle endemic region, the east and southeast were found with high endemicity (12). Different results have been obtained in studies from different regions of our country. Anti HAV IgG positivity was found as $93.9 \%$ in the seroprevalence study conducted by Koseet al, that included 2156 people, aged $\geq 15$ years in Izmir in 2010 . Anti Hav IgG seropositivity was correlated with lower income level, older age, low education level and collective life (military, nursing home, nursery), in this study. The reason for the high seroprevalence was attributed to low education level and income level of most of the participants (13). We could not investigate education level and income level of the participants, as the study is designed retrospectively.

In the study conducted by Ertürk et al. in Rize in 2012, the ages of participants were between 17-70, years and the incidence of HAV infection was reported as $75 \%$ (14). Our study was conducted in people $\geq 18$ years old and HAV seroprevalence was $76.5 \%$, similar to their study.

In 2010, a seroprevalence study that covered all regions of the country, was conducted by Turkish Liver Research Association. Five thousand four hundred and seventy-one adults were tested for HAV IgG and HAV seroprevalence was higher than our study (93.2\%) We think that this high rate may reflect the status in eastern regions of Turkey (15).

If we look at the seroprevalence rates in the studies including children; anti HAV IgG positivity was $74 \%$ in the study of Tosun et al. The study was conducted in İzmir and Manisa and included 3715 subjects. In another study, 2003 people were tested in Sakarya and $74.7 \%$ of them were positive for Anti HAV IgG.

In the study of Parlak et al. 5363 people in Van were evaluated between 2012 and 2013, and Anti HAV IgG positivity was reported as $89.9 \%$. In another study conducted in Batman, 93.9\% of 2606 people with an average age of 34.6 were reported as $\mathrm{HAV}$ IgG positive (16-19). When the results of these studies are analysed, it is seen that HAV seroprevalence is higher in the east part of our country compared to the western and central regions. Our study is conducted in a research hospital in Ankara, reflecting the seroprevalence in central region. We can compare the previous studies with ours' to see the change of epidemiology of HAV infection in Ankara. Tekeli et al. reported, HAV IgG seropositivity 
as $99 \%$ in a study that was between the ages of 20-52 years, in 1991 (20). In another study in 2001, Cesur et al. reported the rate as $87.4 \%$ between the ages of 15-75 years (21). The study by Turker et al. that was carried out in 2008-2010 and, that involved children and adults, the rate was $80.8 \%$ (22). In our study it was found to be $76.5 \%$ and it is lower than past studies carried out in Ankara in similar age groups. In the light of the results of these publications, we see that the rate of the population that is susceptible to HAV has increased in our city and country.

When we examine HAV seroprevalence according to age groups; anti HAV IgG was positive in $99.4 \%$ participants older than 55years, $97.8 \%$ in participants who were in 51-55 age group, $96 \%$ in 46-50 age group and $94 \%$ in $41-45$ age group, in our study. In other studies conducted in İzmir and Afyon, seroprevalence of HAV infection in people older than 40 years was $99,1 \%$, and $97.79 \%$ respectively $(13,23)$. Cesur et al. reported the seropositivity of 15-30 age group as 72.7 in 2001 . Tosun et al. reported this rate as $77 \%$ in adolescents in the age of 15-17 in 2001, and 62\% in 2009 (16, 21, 24). While anti HAV IgG positivity was $54.5 \%$ in the $26-30$ age group and $40.6 \%$ in the $21-25$ age group, this rate drops to $31 \%$ in the $18-20$ age group, in this study. A remarkable increase in the number of people susceptible to HAV infection has been observed in adolescents and young adults over the years. This age group is vulnerable to hepatitis $\mathrm{A}$ in the case of an outbreak.

Improvement of living conditions, infrastructure, hygiene and sanitation conditions and decrease in the number of people living in the same house caused a decrease in the frequency of HAV infection in young children in Turkey, as in the rest of the world. The age of acute hepatitis A infection has switched to adolescence and young adulthood instead of childhood (9). With the inclusion of Hepatitis A vaccine among the routine paediatric vaccines in our country since 2012, the immune population for hepatitis $\mathrm{A}$ in the child age group has increased. But adolescents and young adults are at the risk of acute hepatitis A infection (11). We think that a catch-up vaccination with hepatitis A vaccine will be beneficial for the seronegative population.

Our study has some limitations. Since the study was designed retrospectively, the relationship between patients' demographic data and HAV seropositivity rates could not be evaluated. The study includes the data of one hospital in Ankara. Since our hospital does not have a paediatric diseases department, people under the age of 18 could not be included in the study.

In conclusion, the incidence of hepatitis $\mathrm{A}$ at younger ages decreased with the increase in the socioeconomic level, the development of personal hygiene and sanitation, and the decrease in the number of individuals living in the same house in Turkey. The hepatitis A vaccine, which has been on the child vaccination schedule since 2012, protects children younger than 8 years. However, most adolescents and young adults are at risk of HAV infection and it will be beneficial to vaccinate this group.

Conflict of Interest: None to declare

Support and Acknowledgment: None

Researchers' Contribution Rate Statement: SC conceived and designed research. SC and CS analyzed data and wrote the manuscript.

Ethics Committe Aproval: Dr Abdurrahman Yurtaslan Oncology Hospital Ethics Committe of Clinical Research; date: 13.01.2021, issue number: 2021-01/935.

\section{REFERENCES}

1. Franco E, Meleleo C, Serino L, SorbaraD, Zaratti L. Hepatitis A. Epidemiology and prevention in developing countries. World J Hepatol. 2012;4(3):68-73.

2. Lemon SM, Martin A. Hepatitis A Virus. In: Gorbach SL, Bartlett JG, Blacklow NR, eds. 
Infectious Diseases. $3^{\text {th }}$ edition. Philadelphia. Lippincott Williams \& Wilkins, 2004:2063-71.

3. Curry MP, Chopra S. Acute Viral hepatitis. In: Mandell GL, Bennet JE, Dolin R, eds. Principles and Practise of Infectious Diseases. $7^{\text {th }}$ ed. Philadelphia. Elsevier Churchill Livingstone, 2010:1577-92.

4. Jacobsen KH, Wiersma ST. Hepatitis A virus seroprevalence by age and world region, 1990 and 2005. Vaccine. 2010;28(41):6653-7.

5. Hendrickx G, Van HerckK, Vorsters A, Wiersma S, Shapiro C, Andrus JK et al. Has the time come to control hepatitis A globally? Matching prevention to the changing epidemiology. J Viral Hepat. 2008;15(Suppl 2):1-15.

6. Cristina J, Costa-Mattioli M. Genetic variability and molecular evolution of hepatitis A virus. Virus Res. 2007;127(2):151-7.

7. Feinstone SM, Kapikian AZ, Purceli RH. Hepatitis A: detection by immune electronmicroscopy of a virus like antigen associated with acute illness. Science. 1973;182(4116):1026-8.

8. Sümer Ş, Ural O. Akut Viral Hepatitler. In: Topçu A, Söyletir G, Doğanay M, eds. Enfeksiyon Hastalıkları ve Mikrobiyolojisi. 4. Baskı. İstanbul. Nobel Tip Kitabevleri, 2017:1079-81.

9. Yoldaş Ö, Bulut A, Altındiş M. Hepatit A Enfeksiyonlarına Güncel Yaklaşım. Viral Hepatit Dergisi. 2012;18(3):81-6.

10. Avcı HH, Selçuk EB, Pehlivan E, Elbe H. Türkiye'de yeni bir aşı uygulaması: hepatit A. Euras J Fam Med. 2014;3(1):9-14.

11. Demiray T, Köroğlu M, Jacobsen KH, Özbek A, Terzi, HA. Altındiş M. Hepatitis A virus epidemiology in Turkey as universal childhood vaccination begins: seroprevalence and endemicity by region. Turk J Pediatr. 2016;58:480-91.

12. Ceyhan M, Yildirim I, Kurt N, Uysal G, Dikici B, Ecevit $\mathrm{C}$ et al. Differences in hepatitis A seroprevalence among geographical regions in Turkey: a need for regional vaccination recommendations. J Viral Hepat. 2008;15(Suppl. 2):69-72.

13. Kose S, Mandiracioglu A, Cavdar G, Ulu Y, Nohutcu N, Gurbuz I et al. The seroprevalence of hepatitis A in adults in Izmir: prior to introducing vaccine in to routine vaccination program. Nobel Med. 2013;125:132.

14. Erturk A, Cicek AÇ, Cure E, Akdogan RA, Ozturk C. Seroprevalence of hepatitis A in Rize Province and different adult age groups. Viral Hepatit Dergisi. $2013 ; 19(2) .85-8$

15. Tozun N, Ozdogan OC, Cakaloglu Y. A nation wide prevalence study and risk factors for hepatitis A, B, C, and D infections in Turkey (abstract). Hepatology. 2010:52(Suppl.):697A.

16. Tosun S, Ayaz H, Deveci S, Aksu S. Evaluation of the contact status of the children and adults with Hepatitis A virus. Proceedings of the 10th National Congress of Viral Hepatitis. Antalya. 2010:121-34.

17. Koroglu M, Demiray T, Terzi HA, Altindis M. Seroprevalence of hepatitis A among different age groups in Sakarya and review of theliterature. Viral Hepatit Dergisi. 2014;20(3):110-4

18. Parlak M, Guven A, Erdin BN, Bayram Y. Seroprevalence of hepatitis-A virus among child and adult age groups admittedt o a training and research hospital. Viral Hepatit Dergisi. 2015;21(1):20-2.

19. Demirpence O, Tezcan SI, Degirmen E, Mert D, Gumuş A, Celen MK. Seroprevalence of HAV, $\mathrm{HBV}, \mathrm{HVC}$ and HIV in people admitted to Batman State Hospital. Viral Hepatit Dergisi. 2012;(18)1:610.

20. Tekeli E, Wilke A, Balık A. Kan vericilerin serumlarında hepatit A virus antikorlarının araştırılması. 3. Ulusal Enfeksiyon Hastalıkları Kongresi, Kongre Kitab1, 22-26 Nisan 1991, Antalya. Kongre Kitab1. 1991:330-1. 
21. Cesur S, Akin K, Dogaroglu I, Birengel S, Balik I. Hepatitis A and hepatitis E seroprevalence in adults in the Ankara area. Mikrobiyol Bülteni. 2002;36(1):79-83.

22. Turker K, Balci E, Bati S, Hascuhadar M, Savas E. Ülkemizde hepatit A enfeksiyonunun değişen epidemiyolojisi. Türk Mikrobiyol Cem Derg. 2011;41(4):143-8.

23. Asc1 Z, Akgun S, Kesli R, Demirturk N. Seroprevalence rates of Hepatitis A virus in different age groups in the province of Afyonkarahisar. Göztepe Tip Dergisi. 2014;29(2):94-8.

24. Tosun S, Ertan P, Kasirga E, Atman U. Changes in seroprevalence of hepatitis $\mathrm{A}$ in children and adolescents in Manisa, Turkey. Pediatr Int. 2004;46(6):669-72. 